\title{
ЮРІЙ ВИННИЧУК ЯК УПОРЯДНИК УКРАЇНСЬКОЇ ЛІТЕРАТУРНОЇ СПАДЩИНИ
}

\author{
ПШЕМИСЛАВ ЛІС-МАРКЕВІЧ \\ Університет імені Адама Міцкевича, Познань - Польща \\ przemyslaw@lis-markiewicz.pl \\ JURIJ WYNNYCZUK JAKO AUTOR WYBORU TEKSTÓW \\ UKRAIŃSKIEJ SPUŚCIZNY LITERACKIEJ \\ PRZEMYSŁAW LIS-MARKIEWICZ \\ Uniwersytet imienia Adama Mickiewicza, Poznań — Polska
}

STRESZCZENIE. W artykule dokonana została analiza działalności Jurija Wynnyczuka jako autora wyboru tekstów. Podjęto próbę definicji antologii jako gatunku literackiego, zwięźle przedstawiono poszczególne antologie i zbiory tekstów pisarza oraz określono jego wkład w rozwój współczesnej literatury ukraińskiej.

\section{YURIY VYNNYCHUK AS A COMPILER OF UKRAINIAN LITERARY HERITAGE}

PRZEMYSŁAW LIS-MARKIEWICZ

Adam Mickiewicz University, Poznan — Poland

ABSTRACT. The article is an attempt to come out with Yuriy Vynnychuk's compiling activity. The author tries to analyse anthology as a separate literary genre, the brief description of Vynnychuk's collectanea has been presented. The prominent contribution of the writer into contemporary Ukrainian literature has been discerned.

$\Pi$

остать Юрія Винничука в сучасній українській літературі є досить помітною, а його творчий доробок - значний та різноманітний. Читачам періодики Ю. Винничук більш відомий під псевдо Юзьо Обсерватор. Письменник вирізняється талантом й у видавничій та укладацькій діяльності. Цей напрям його активності можна розглядати у двох аспектах: упорядника і видавця різноманітних антологій і редактора газети „Рost-Поступ”. Укладацька діяльність письменника ніколи не була предметом усебічного наукового дослідження (окремі аспекти творчої діяльності Винничука вивчали поодинокі літератори깅, хоча Ю. Винничук досяг у цій сфері значних успіхів. Він спроек-

' Див.: напр., Ярослав Голобородько (Я.Гол о б о р одь ко, Нова українська альтернатива: епатажна естетика Винничука, [в:] „Українська мова та література” 2006, ч. 9, с. 11-14.), Василь Карвацький (В. Карв аць ки й, Юрій Винничук як дзеркало “модерного галичанства”, [в:] „Кур’єр Кривбасу” 2003, № 165, с. 200-204), Ірина Ковбаса (І. Ко в бас а, Містифiкатор Винничук, [в:] Електронний ресурс: http:// litakcent.com/2009/04/25/ iryna-kovbasa-mistyficatorvynnychuk (02.03.2017)); Богдан Лук'янів (Б. Лук'ян ів , “Чемоданні” твори Юрія Винничука, [в:] „Березіль” 2003, № 9-10, с. 180-182), Володимир Павлів (В. П а в л і в , Гробокопач украӥнської літератури (до 40-річчя з дня народження Ю. Винничука), [в:] „Post-Поступ” 1992, ч. 9), Микола Рябченко (М. Рябченко, Концепт маски в творчості Юрія Винничука, Київ 2013, с. 26-32.), Жанна Степанець (Ж. Ст еп ан е ць, Юрій Винничук, [в:] „Українська мова та література” 2008, № 13-16, с. 100.); Роксана Харчук (Р. Харчук, Юрій Винничук - батько чорного гумору в украйнській літературі, [в:] Ї̈̈ ж, Сучасна украӥнська проза: Постмодерний період, Київ 2008, c. 122-125) та ін. 
тував свій погляд на українську романтичну та готичну фантастику XIX ст. Огнений змій (1989), українську літературну казку XIX ст. - Срібна книга казок (1993), Зачароване місие (2006), краєзнавчу літературу - Легенди Львова (1999), Кнайпи Львова (2000), Таємниці львівської кави (2001), Нічний привид: Українська готична проза XIX cm. (2001, 2007), книги казок деяких районів Львівщини - Казкова скарбниия (2002), міфологічну енциклопедію - Книга Бестій (2003), Чорт зна що (2004), Потойбічне. Украйнська готична проза ХХ ст. (2005), Тасмниці львівської горілки (2006), Розіп'ята Муза. Антологія українських поетів, які загинули насильнииькою смертю (2011), Антологія української готичної прози у 2 томах (2014), Антологія української фантасти$\kappa и ~ X I X-X X \mathrm{~cm}$. (2015). Попри те, що антологію зазвичай називають популярним жанром, комерційним проектом, саме вона привернула увагу письменника. Тому варто встановити, чи фахово Ю. Винничук підбирає авторів, чи вивіряє матеріал, чи дбає про його цілісність, значення для розвитку науки тощо.

Таке видання (антологія), на жаль, нечасто стає предметом філологічного аналізу². Звідси - відсутність жанрового визначення подібних видань, однозначності в їхньому трактуванні, чіткої дефініції, оскільки антологію радше розглядають як видавничий проект, у якому автор-укладач підсумовує вже знане, відоме, об'єднуючи під однією обкладинкою доволі різних письменників за світоглядом, наративною стратегією, стилем письма. Однак такі книги часто заповнюють прогалину в літературознавчій науці, що повинна була б дати адекватну оцінку тому чи тому літературному явищу. 3 цього погляду антології та їхні укладачі випереджають дослідників-філологів, готують грунт для подальших наукових студій, адже основна ознака таких видань - фактографічність.

Укладач насамперед керується ціннісними пріоритетами у відборі та опрацюванні матеріалу: зважає на місцевість, де народилися письменники, тематику їхніх текстів, гендерну приналежність, локальність появи літературного явища тощо. Усе це стає визначальним у способі подачі матеріалу. Часто це виказує крайні суб'єктивні уподобання упорядника. Те, що пропонує упорядник, стає літературною акцією, подією. Передусім це сприймається як ревізія літературної традиції та канону, їхня актуалізація, увиразнення тяглості та перспектив розвитку української літератури. Нерозривно із цим існує розуміння того, що література у формі антології зберігає культурну пам'ять, а значить, ідентичність, особливо в умовах офіційної заборони та репресій. Антології стають архівом, бібліотекою збережених творів українських письменників. „Так само за принципом архівної повноти побудовані антології, які повертають у національну традицію окремі жанрово-родові чи стилістичні феномени, зокрема й угруповання, що спромоглися на власні естетичні пропозиції (Молода Муза В. Лучука, 1989; Українська хата В. Шевчука, 1990; Стрілещька Голгофа та Слово Благовісту Т. Салиги, 1992, 1999 та інші”, — пише дослідниця антологій О. Галета ${ }^{3}$. Такі упорядковані видання можна сприймати як переписування вже опублікованих колись текстів, однак їхня вписаність у сучасний літературний процес із новими методологічними можливостями створює перспективу для нових інтерпретацій традиційних художніх текстів. Усупереч ідеологічним настановам та ціннісним орієнтаціям антологія презентує ту необхідну суб'єктивність, що заохочує читацький інтерес, формує культурний простір. До таких видань

\footnotetext{
2 Див.: напр.: О. Галета, Антологія як репрезентативний жанр нової української літератури, [в:] „Питання літературознавства” 2013, № 88, с. 157.

${ }^{3}$ Там само, с. 159.
} 
можна зарахувати Декамерон. 10 украӥнських прозаїків останніх десяти років4 чи Сновиди .

Антологійний бум в Україні розпочався наприк. 80-х - поч. 90-х років $\mathrm{XX}$ ст. Поява все нових і нових видань дає підстави стверджувати, що цей процес успішно триває в сучасній українській літературі ${ }^{6}$. Чим зумовлена така мода на антології, які іронічно називають братськими могилами? Насамперед це наслідок катастрофічної кризи книгодрукування на Україні впродовж 90 -х років ХХ ст. На той час не відбулося очікуваного літературного зростання у зв'язку з вибореною державністю. Навпаки, літературний спад, що його зазвичай пов'язують $з$ тотальною суспільною депресією, змусив багатьох українських письменників друкуватися в колективних збірниках або писати в шухляду, оскільки не було попиту на українську книжку. В умовах ринку, неконтрольованої комерції, уседозволеності книговидавничий процес став занадто дорогим, держава не дотувала навіть свої видавництва. Саме тому вони зменшували кількість книг, загальний тираж та збільшували тиражі так званих ходових книг. До останніх не завжди належали книги найвищої художньої якості, що знижувало і читацький смак, і загальний культурний рівень народу.

У такий спосіб українські письменники заявляли про свою творчість, через антології утверджувалися талановиті особистості різних художніх систем, уподобань і напрямків. Саме творчість Ю. Винничука поряд з іменами О. Забужко, Ю. Андруховича, I. Римарука та ін. стали асоціювати з новоякісними змінами в українській художній ментальності. Передусім через європеїзацію витворюваної ними естетики.

Тривале зацікавлення Ю. Винничука готикою, інфернальними станами, міфами в українській літературі й укладання антологій з цього небуденного, екзотичного матеріалу можна вважати наслідком тих посутніх змін, що відбулися в сучасному літературному процесі України. Насамперед це те, що література зі здобуттям незалежності позбулася ідеологічного та партійного диктату, свобода і плюралізм у творчості спонукали до культивування тем, на які раніше було накладено табу (еротика, злочинність, психічні хвороби, бомжування, проституція, пияцтво та ін.). Саме тоді зародилася ідея різноспрямованості літературного процесу, виникла реакція на простоту народницької і соцреалістичної образності — нова література нового рівня.

4 Декамерон - антологія сучасної української прози (2010), до якої ввійшли нові оповідання десяти популярних вітчизняних письменників: Софії Андрухович, Любка Дереша, Анатолія Дністрового, Сергія Жадана, Ірени Карпи, Світлани Пиркало, Світлани Поваляєвої, Тараса Прохаська, Наталки Сняданко, Сашка Ушкалова.

${ }^{5}$ Сновиди. Сни українських письменників (80 авторів) - антологія, видана Т. Малковичем, до якої ввійшли повісті й романи 80-ти сучасних українських письменників різних поколінь.

${ }^{6}$ Див.: напр.: Вісімдесятники: Антологія нової української поезї̈, упоряд. І. Р им а рук, передм. М. Рябчук, Едмонтон 1990, 205 с.; Антологія сучасної української поезії. Десять українських поетів; Антологія сучасної української прози. Десять українських прозаїків, Київ 1995, 256 с.; Квіти в темній кімнаті: Сучасна українська новела, упор., прим., передм. В. Дан и ле н к а, Київ 1997, 432 с.; Вечеря на дванадиять персон: Житомирська прозова школа, упор., передм., літ. ред. В. Дан иленка, Київ 1997, 544 с.; Плерома: Мала українська енщиклопедія актуальної літератури, Ів.-Франківськ 1998, 287 с.; Опудало: украӥнська прозова сатира, гумор, іронія 80-90-х років XX cm., упоряд., передм., літ. ред. В . Дан и ле н ка, Київ 1997, 384 с.; Антологія українського жаху, упоряд. В. Пах ар е н ко, Київ 2000, 800 с.; Приватна колекиія: Вибрана українська проза та есеїстика кіния XX cm., упор., вступн. слово та прим. В. Га б ор а, Львів 2002, 628 с.; Жінка як текст: Емма Андієвська, Соломія Павличко, Оксана Забужко: фрагменти творчості і контексти, упор. Л. Таран, Київ 2002, 208 с.; Незнайома. Антологія „жіночої” прози та есеїстики др. половини $X X-$ поч. $X X$ cm., автор. проект, упор., вст. слово В . Габо ра, Львів 2005, 600 с. та ін. 
Розпочавши свою творчу діяльність на початку вісімдесятих у майже 30-річному віці Ю. Винничук одразу ж був зарахований до когорти авторівнонконформістів ${ }^{7}$, які не сприймали офіційну радянську ідеологію та кожен у свій спосіб намагалися їй протистояти, принаймні на терені літератури. Можемо окреслити генезу авторського стилю як таку, що розвивається від готичних (таємничість, типова образність, гротеск), романтичних (пошук ідеального кохання, двосвіття) та ранньомодерних (бурлеск, епатаж, пародія) настанов у творчості до стилізацій та містифікацій цілком постмодерного світогляду. „Для того, щоб виявити щось цікаве в несучасній давно забутій прозі, треба заново відкрити іiї, відредагувати, упорядкувати, актуалізувати й зробити доступною. Охочих займатись цим не так багато, адже подібна робота вимагає тривалого перебування в архівах та пошуків старих часописів", - зазначив Ю. Винничук ${ }^{8}$. Задля цього письменник побував у багатьох найбільших бібліотеках світу, а також створив власну бібліотеку, протягом свого життя прочитав багато творів не тільки української, а й світової літератури. „Читати я люблю дужче, аніж писати. Якби було можливо, я б ніколи нічого не писав, а тільки читав, читав, читав... I тисячу літ, або й дві... Ще я люблю мріяти. У мене багато мрій. В одній 3 них я - безсмертний полководець, який має 10 тисяч безсмертних воїнів і може виправити історію", - зізнається автор. Чи немає в цій мрії проекції на його укладацьку діяльність, адже це теж спроба заповнити прогалини в масовій свідомості, виправити минуле, привернути увагу до давно забутих текстів, авторів, щоб у такий спосіб витворити цілісну картину українського повновартісного культурного життя впродовж його історично несприятливого існування?

Упорядковані Ю. Винничуком антології можна назвати масовими літературно-художніми виданнями. У поле зору письменника потрапили ті видання, що, по-перше, найяскравіше презентують його зацікавлення фантастикою, готикою, народною демонологією, міфами (Огненний змій, Потойбічне, Чорт зна що, Книга Бестій), по-друге, оприявнюють його захоплення краєзнавчою літературою, зокрема давніми традиціями Львова (Кнайпи Львова, Леген$\partial u$ Львова), по-трете, розкривають його потенціал як дослідника історії української літератури в проекті Розіn'ята Муза, як упорядника української казки в проекті Срібна книга казок, вияскравлюють його пошуковий, креативний потенціал проектом Львівська антологія, особистісні зацікавлення зразками світової літератури проектом Юрій Винничук презентує. Для того, щоб виявити фаховість у виборі матеріалу, простежити, чи включені до антології твори утворюють структуровану єдність, що не зводиться до сукупності окремих творів, дослідити, чи упорядковані тексти репрезентують певні естетичні цінності, варто вдатися до аналізу окремих творів із кожної антології. Це дасть змогу з'ясувати ретельність автора у відборі матеріалу, його орієнтацію на читача (за жанрово-стильовою специфікою, тематикою, проблематикою, домінантними образами, актуальністю, новизною), установити репрезентативність, повноту, універсальність усього дібраного матеріалу, що забезпечить висновок про інформативний, культурний, естетичний, виховний рівні укладених письменником антологій.

7 Л. Медведєва, Історіографія нонконформізму в украйнському образотворчому мистеитвві 60-х рр. ХХ ст., [в:] Мистеитввознавчі записки, зб. наук. праць, Київ 2002, с. 2. c. 98 .

${ }^{8}$ Ж. Сте панець, Юрій Винничук, [в:] „Українська мова та література” 2008, № 13-16, 
Працюючи над виданнями, Ю. Винничук знайшов та відновив багато стародавніх літературних оповідань. Однак сучасному дослідникові творчості письменника, окрім вивчення опублікованих книг, варто звернути увагу й на його інтерв'ю9 , у яких Ю. Винничук зізнається в численних містифікаціях. Так були опубліковані нібито знайдені тексти XIII та XVII століть Ріангабара ${ }^{10}$ i Анни Любовичівни. ${ }^{11}$ Після гучних схвальних відгуків на адресу середньовічного автора та сумлінного упорядника, після того, як тексти увійшли в науковий обіг і словникові статті, Ю. Винничук зізнався, що ці тексти належать йому. У такий спосіб успішна вигадка стала претендувати на достовірний факт з історії української літератури.

Перекладаючи та упорядковуючи видання давньої літератури, Ю. Винничук теж удавався до містифікацій. Так, оповідання Iсторія черепа Ореста Авдиковського Ю. Винничук подав за часописом „Галицкая Русь” 1892 року. Проте насправді, як стверджує дослідниця Винничукових містифікацій I. Ковбаса, у цьому виданні вказаний текст відсутній. Орест Авдиковський - особа реальна. Як пише І. Ковбаса, містифікації відбулися з оповіданням Кімната Привидів невідомого автора. Упорядник зазначив, що взяв твір із часопису „Annales des sc. Psych” („Аннали психічних наук”) 1891 року. Оскільки відсутнє й ім’я автора, текст також не слід шукати ${ }^{12}$.

Укладач доволі часто нехтує академічними нормами, упорядковуючи антології. Наприклад, він не зазначає джерел текстів або вказує помилкові. Про Григорія Луцика-Муллика та його оповідання теж відсутня будь-яка інформація. Відомості про Григорія Луцика-Муллика і його тексти можна знайти тільки в антології Ю. Винничука Потойбічне, проте вони дуже лаконічні. До того ж, упорядник подає неконкретизовані біографічні нотатки, узагаьнено описує періодику й час, коли публікувалися тексти Григорія Луцика-Муллика. Про творчий доробок письменника сказано теж лаконічно. Спроба I. Ковбаси відшукати його серед усієї картотеки фонду була безуспішною. Очевидно, потрібно кількаразове звернення до рукописного фонду, аби остаточно впевнитися у відсутності документа. Не вдалося дослідниці знайти і певних біографічних даних про письменника. Однак Г. Луцик-Муллик зі своїми текстами вже присутній на кількох інтернет-сторінках: „Архівові фантастики” і „Офіційному сайті письменника-фантаста Олександра Левченка”. Як і у випадку з Iсторією череnа та Кімнатою привидів, це свідчить про ефект розростання вигадки. Г. Грабович в одній зі своїх студій називає такий процес канонізацією містифікації ${ }^{13}$.

Огненний змій - перше упорядковане видання творів фантастичного спрямування Ю. Винничука ${ }^{14}$. До неї ввійшли такі твори: Запропаща грамота (Бувальщина) Миколи Гоголя, От тобі і скарб Г. Квітки-Основ'яненка, Київські

${ }^{9}$ Ю. Винничук співбесідник численних інтерв’ю, між іншим: Винничук: „, У нас має бути гонор”, [в:] Електронний ресурс: http:// litakcent.com/2011/04/01/jurij-vynnychuk-u-nas-majebuty-honor/ (02.03.2017); Ю. Винничук: „Украӥнській політиці бракує украӥнського Піночета, а літературі - української Джоан Ролінг”, [в:] „Телекритика” 2003, 13 листопада.

10 Ріангабар — вигаданий сучасним українським письменником Юрієм Винничуком ірландський поет, який нібито 1240 року був свідком сплюндрування Києва військами Батия та описав ці події у вірші-ламентації Плач над градом Кия.

11 М. Рябчен ко, Конщепт маски в творчості Юрія Винничука, Київ 2013, с. 26-32.

${ }_{12}$ I. Ковбаса, Містифікатор Винничук, [в:] Електронний ресурс: http://litakcent.com/ 2009/04/25/ iryna-kovbasa-mistyficator-vynnychuk/ (04.03.2017).

${ }_{13}^{13}$ Там само.

${ }^{14}$ Див.: Огненний змій: Антологія украӥнської фантастичної прози, упоряд. Ю. П.В и н н и чук, Київ 1989. 
відьми Ореста Сомова, Золота гора, або я тебе врятую (Істинно українська легенда) Михайла Чайковського, Недобрий вішун, Втоплениия, Як нажито, так і прожито Хоми Купрієнка; Огненний змій (Повість з народних переказів) Пантелеймона Куліша, Журавель Юрка Юрченка, Нічний супутник Івана Наумовича, Чортова пригода Марка Вовчка, Закоханий чорт Олекси Стороженка та інші. Передмову до видання У світі фантазій українського народу написав В. Шевчук, У зачарованім люстрі: від упорядника — сам Ю. Винничук.

2006 року Ю. Винничук уклав і видав другий том збірника Огненний змій, куди увійшли передруковані й нові зразки української романтичної фантастики позаминулого століття: Мертвеиький Великдень, От тобі і скарб Г. КвіткиОснов'яненка, Русалка, Київські відьми, Недобре око, Цвіт папороті (Уривок із повісті Перекази про скарби) Ореста Сомова, Закоханий чорт, Чортова корчма О. Стороженка, Страшна помста Миколи Гоголя, Недобрий вішун, Втоплениия, Як нажито, так і прожсто Хоми Купрієнка, Дитяча могила, Хвора (розповідь лікаря), Фаӥна М. Костомарова, Огняний змій: повість із народних переказів, Про те, що сталося з козаком Бурдюгом на зелені свята П. Куліша, Біс на вечорнииях, Витівки духів, Примари, Прогулянка дідька Г. Данилевського та інших знаних і невідомих авторів. Уведення до літературного кола творів малознаних письменників значно розширює уявлення українців про літературу XIX ст., дає можливість усвідомити, що белетристика не обмежується лише літературним каноном, а претендує на ії докладне дослідження та поцінування шляхом уведення нового матеріалу.

Обидва видання, упорядковані Ю. Винничуком, доповнюють та укомплектовують багатотомну бібліотеку української фольклорної демонології, змінюючи уявлення широкого кола читачів про фантастичну літературу. У передмові до антології Огненний змій Ю. Винничук розповідає про тривале зацікавлення цією темою. За його словами, „оригінальним українським внеском до скарбниці світової фантастичної літератури є саме казкова, або міфологічна фантастика, написана з гумором, дотепністю, а деколи відчутне тут і кепкування автора над самим читачем"15.

Виразною ознакою укладеної Ю. Винничуком антології $\epsilon$ iї демонологічний компонент, тобто використання українськими письменниками XIX ст. запозичених із фольклору міфологічних уявлень та вірувань у нечисту силу потойбіччя, що в різних формах постійно з'являється в земному світі. За системою світоглядних уявлень українців, світ поділений на сфери впливу надприродних істот, які через свою велику кількість не досягли статусу богів, а утвердилися в значенні божеств або по-іншому демонів. У кожному тексті присутній такий демонічний персонаж або ж потойбічний світ (Хома Масляк - От тобі і скарб, Федор Блискавка - Київські відьми, Горпинка - Русалка, Данило - Страшная месть, Петро - Заклятий козак), а тому означувати прозу фантастичною, тобто такою, що апелює лише до вигадки, незвичних образів, які не мають аналогів у дійсності, не фахово.

Потойбічне 16 - збірка укладених Ю. Винничуком творів про потойбічний світ. Привиди, духи, містичні сцени, таємничі місця - увесь цей похмурий антураж прийнято вважати прикметними ознаками готичної прози. Письменник помістив до антології твори не лише класиків літератури (І. Франка, В. Стефаника, Б. Лепкого, М. Яцкова, Г. Хоткевича), але й розшукав для цього ви-

\footnotetext{
${ }^{15}$ Там само, с. 9

${ }^{16}$ Ю. Винни чук, Потойбічне, Львів 2005, с. 283.
} 
дання маловідомі твори, що публікувалися в довоєнних та зарубіжних часопиcax, оприявнив недосліджену українську готичну прозу. До збірки увійшла така проза: Терен у нозі Івана Франка, Мати, Небіжчик, Старий двір, Гостина Богдана Лепкого, Басараби, Нитка В. Стефаника, У пітьмі ночі, Антіна Крушельницького, 3 днів розпуки Олени Кисілевської, Камелії Павла Богацького, Порmрет, Біла Гната Хоткевича, Петля Ю. Будяка, В старих палатах Надії Кибальчич, Погроза невідомого Гната Михайличенка, Семиковецькі тіні Клима Поліщука, Трагічний сеанс, Жах Г. Луцика-Муллика, Капелюх із зеленим пером, Уnup, B мочарах Федора Потушняка та інші твори. Так письменник ліквідовує білі плями в історії української літератури, у готичній зокрема. Це видання покликане, хоч і невеликою добіркою творів, нагадати сучасному читачеві помітні й несправедливо забуті та напівзабуті творчі особистості цікавих прозаїків, а разом з тим дати уявлення про цілісність такої прози — про тї багатство та різноманітність. В антології репрезентовані письменники к. XIX - перших десятиліть XX ст.

Наступна збірка Чорт зна що ${ }^{17}$ Ю. Винничука присвячена загадковому, однак поширеному персонажеві багатьох фантастичних творів світової літератури, зокрема й української, - чортові. „Маленькі, чорненькі, вертляві, з ріжками, свинячим п'ятачком, копитцями і хвостом, вони були всюдисущі та надзвичайно живучі" 18 , - так їх уявляли. Селяни вважали, що копітка праця на землі не може принести багатства, великих грошей. Багатіли так звані занятники - люди, які мали гроші від заняття, що приносить бариш. Стати таким можна лише продавши душу чортові. Окрім того, зло, що його чинили чорти, наводило на думку про те, що нечиста сила задумала звести зі світу увесь рід людський. Але якщо ти смілива, упевнена в собі людина, то нечисті можна було не боятися. „Не такий чорт страшний, як його малюють”, „Хай чорт як не скаче, то скаче, а ти своє роби" 19 , - так повчала народна мудрість не боятися темних сил.

До збірки увійшли апокрифи та моторошні оповіді отців церкви: Петра Могили, Михайла Андрелли, Стефана Яворського, Іоаникія Галятовського, Дмитра Тупталенка, літописців Нестора та Самійла Величка, українських письменників XIX-XX ст. (Л. Боровиковського, О. Стороженка, П. Куліша, Ганни Барвінок, Н. Кобринської, В. Стефаника, І. Франка, В. Самійленка, С. Васильченка, Наталени Королевої; В. Дрозда, В. Шевчука, Е. Андієвської, В. Єшкілєва, Ю. Андруховича) та ін. Чимало творів перекладені зі староукраїнської, російської, польської та латинської мов.

Також до переліку збірок фантастичної літератури Ю. Винничука можна зарахувати двотомник Розіn'ята муза $a^{20}$ - антологію українських письменників, які загинули мученицькою смертю від рук денікінців, більшовиків, німецьких загарбників, сталінського режиму, полягли на фронтах Першої та Другої світових воєн, померли на засланні та в концтаборах.

Упорядник антології Ю. Винничук розшукав і відкрив понад сотню раніше невідомих авторів, які публікувалися в періодиці перш. пол. XX-го ст., уточнив роки смерті багатьох поетів за протоколами трійок, відшукав поезії письменників, про яких досі не все було відоме (Г. Косинка, В. Чечвянський, Ю. Вух-

${ }^{17}$ Ю. Винничук, Чорт зна щзо, Львів 2004, с. 792.

${ }^{18}$ В. Супру нен ко, Народини. Витоки нації: символи, вірування, звичаї та побут українців, Запоріжжя 1993, с. 123.

${ }^{19}$ Там само.

${ }^{20}$ Ю. В ин н и чук, Розіп'ята Муза. Антологія украӥнських поетів, які загинули насильницькою смертю, Львів 2011. 
наль, Д. Бузько та ін.). Усього в антології репрезеновано 322 автори. Серед них такі, як: Іван Журбенко, Лев Лопатинський, Теофіль Мелень, Іван Балюк, Юліан Назарак, Юрій Мандрик, Корній Гуленко, Іван Стешенко, Юрій Кравченко, Андрій Заливчий, Дмитро Самойлович, Степан Грещенко, Дмитро Вітовський, Василь Чумак, Гнат Михайличенко, Павло Савченко, Іван Гриценко, Степан Бабак, Митрофан Король, Михайло Гаврилко, Григорій Чупринка, Олександр Грудницький, Петро Гаєнко, С. Іванченко, Павло Мазюкевич, Сидір Твердохліб, Микола Міхновський, Максим Вдовиченко, Аркадій Казка, Павло Коломієць, Яким Терехович, Петро Гірняк, Тимофій Іващенко, Микола Хвильовий, Яків Жарко, Марійка Дика, Михайло Грушевський, Свдокія Біла та ін.

До другого тому ввійшли твори Миколи Філянського, Миколи Чернявського, Василя Бобинського, Антіна Приходько, Бориса Манжоса, Андрія Хвилі, Мелетія Кічури, Василя Ворульського, Юрія Сомка, Юрія Жилко, Миколи Калинчука, Миколи Вороного, Миколи Крикуна, Володимира Затонського, Олександра Соколовського, Миколи Сімашкевича, Вероніки Черняхівської, Івана Кириленка та багатьох ін. Головними складниками світогляду українських інтелектуалів був бунт, самостійність мислення та щира віра у власні ідеали. Саме тому тоталітаризм розпочав наступ супроти інтелігенції, аби шляхом її фізичного винищення духовно обезглавити народ, позбавити його перспективи національного відродження.

Ю. Винничук не просто збирав вірші загиблих поетів, а й детально вивчав їхні біографії. Це дало йому змогу відкрити чимало нових імен, показати їхню оригінальну творчість. За словами автора, праця над Розіn'ятою музою неймовірно цікава ще й тим, що деякі поети, які вважалися загиблими на війні чи зниклими без вісти, насправді переховувалися й помирали своєю смертю. Таких імен небагато, здебільшого про них Ю. Винничук дізнавався завдяки спогадам їхніх родичів ${ }^{21}$. Антологія Розіn'ята Муза - промовистий мартиролог інтелекту української нації, яка, окрім Голодомору, зазнала ще й таких жахливих спустошень у культурі, яких не зазнала жодна інша. Подвижницька праця упорядника, який збирав матеріали до антології понад 10 років, заслуговує окремого визнання.

Цікавими видаються Винничукові зізнання про те, що під час укладання антології з ним діялися містичні речі. Йому щось перешкоджало написати власний роман, проте затишно було лише в бібліотеці, де він шукав і фотографував матеріали. Навіть дружина остерігалася відволікати його від роботи, бо вже „дещо горіло, падало, розбивалося, не вдавалося, не проростало, засихало, підгнивало..." 22 . Сприяла навіть погода. Своєю антологією Ю. Винничук спробував подолати суспільне безпам'ятство, недбальство у ставленні до тих, хто був занесений у чорні списки ворогів народу, але віддав вогонь свого серця Україні. Антологію можна означити словами Олеся Гончара як книгу „великого народного болю, книгу, що й до нащадків перейде як грізне свідчення, як прокляття сталінщині, як реквієм по незліченних людських жертвах, так немилосердно, так безневинно вигублених на очах цивілізованого XX віку"²3.

${ }^{21}$ Ю. Винничук, Слово про розіn'яту музу, [в:] Його ж, Розіп'ята Муза. Антологія украӥнських поетів, які загинули насильницькою смертю, Львів 2011, т. 1., с. 9.

22 I. Ковбаса, Містифікатор Винничук, [в:] Електронний pecypc: http:// litakcent. com/2009/04/25/ iryna-kovbasa-mistyficator-vynnychuk/ (05.02.2017).

${ }_{23} 3$ порога смерті: Письменники Украӥни - жертви сталінських репресій, [в:] „Рад. письм.” 1991, № I, c. 489. 
Привертають увагу краєзнавчі антології Ю. Винничука: Кнайпи Львова, Легенди Львова, Таємниці львівської кави та інші. Така праця вимагала від упорядника опрацювання величезної кількості літератури: копіювання, переписування, вивчення, зіставлення, перевірки джерел. Тим більше, якщо це стосувалося давнього побуту Львова. В одному з інтерв'ю письменник зізнався, що така робота збагатила його знаннями: „Я знав все про те, як колись одягалися львів’яни, що їли і в яких рестораціях. Багато приміщень 3 тих часів збереглося, хоча зараз там магазини, офіси" ${ }^{24}$. Після публікації книги Кнайпи Львова ${ }^{25}$ виникло багато проектів 3 відтворення старих кнайп. Кнайпа - це щось на зразок невеликого ресторану низького класу ${ }^{26}$. У книжці розповідається про львівські кнайпи XIX і перш. пол. XX ст. Книга може слугувати своєрідним путівником по тодішньому Львову, адже 3 кожною кнайпою пов'язана своя історія і своя легенда, і всі вони розкривають неповторний образ Львова. У кнайпах часто збиралась літературна інтелігенція. Хоча, як пише Ю. Винничук, у деяких львівських кнайпах не завжди „клієнт був паном”. Наприклад, у кнайпі Кноблюха „всередині було так, як мовби в якомусь льоху, де зазвичай тримали бульбу”: не було ані склянок, ані келишків, а відвідувачі пили 3 „чвертьлітрових бляшаних кубків, котрі були ще й примоцовані до столів ланцюжками, довжини яких вистарчало тільки на те, аби кубок досягнув писка"27. Такі заклади називалися мордовнями. Розділи книги „Львівських каварень чар”, „Найславетніші кнайпи”, „Цукерні”, „Готелі”, „Касино”, „Шинки, корчми, мордовні”, „Каварняна хроніка" добре ілюстровані та доповнені газетними хроніками, зразками міського фольклору.

Книга Бестій ${ }^{28}$ - своєрідна енциклопедія народних вірувань. Збірка містить розповіді про міфічних істот, яких ще називають бестіями - чудернацьких тварин або істот, якими здавна лякали людей, бо вони приносять негаразди та невдачі. Зазвичай вони мають вигляд усіляких звірів зі страшними зубами та пазурами. Бабин Пес, Безносі, Дикі жінки, Дипса, Діти-чудовиська, Довгомуд, Енотокети, Еринії, Єхидна, Схинія, Жар-птиця, Залізноголові риби, Змії Крилаті, Змія-Діва, Змія, Лага-Цариця, Ідроп, Калбей, Кампа, Камфур, Канідул, Каркаданн, Катанії, Кентаври, Леволюди, Черепаха-велетень, Ящір та ін. - стали об'єктами художньої інтерпретації письменника. Чимало істот письменник запозичує з міфів та легенд давнього світу.

Львівська антологія ${ }^{29}$ Ю. Винничука - збірка у трьох томах літературних надбань Львівщини від давніх часів і до початку XX ст. Створювати антологію літератури Львова письменникові, очевидно, було складно через розмаїття матеріалів, із яким доводилося працювати. Юрій Котермак (Дрогобич), Павло Русин з Кросна, Себастіян-Фабіян Кльонович, Миколай Рей, Симон Симонід (Шимон Шимонович), Симон Пекалід, брати Зиморовичі - Бартоломей і Симон - усі вони писали то латиною, то польською, але проявили себе великими патріотами Русі. Завдяки діяльності подвижника Івана Левицького, який уклав грунтовну бібліографію українських видань, виключно $з$ детальним змісc. 99 .

${ }^{24}$ Ж. Степанець, Юрій Винничук, [в:] „Українська мова та література” 2008, № 13-16,

${ }^{25}$ Ю. Винничук, Кнайпи Львова, Львів 2001, с. 290.

${ }^{26}$ Кна́йna (від нім. Кnеipe) - корчма, шинок, пивниця, генделик — гастрономічний заклад, де подають насамперед спиртні напої.

${ }^{27}$ Ю. Винничук, Кнайпи Львова - пораз другий, [в:] „Поступ” 2001, 22-23 вер.

${ }^{28}$ Ю. Винничук, Книга Бестій, Львів 2003, с. 292.

${ }^{29}$ Ю. В инничук, Львівська антологія, Харків 2013, т. 1, с. 667, т. 2, с. 412. 
том кожного часопису, Ю. Винничук мав змогу отримати повну картину літератури XIX ст., проте не вся література того часу прочитана і досліджена загалом. Перший том антології - твори українських класиків, менш відомих авторів, класиків польської і австрійської літератури, що були пов'язані зі Львовом і Львівщиною. У виданні представлені народні та літературні казки.

Поряд з укладанням збірок фантастики, міфологічних легенд Ю. Винничук також збирає казки та оповідання. Хоча він і сам $€$ автором казок та інших дитячих творів, за якими навіть знято мультфільми, проте це не заважає йому цікавитися казками інших авторів, українськими народними казками чи іноземними дитячими творами.

Досить різноманітні твори українських та зарубіжних авторів Ю. Винничук об'єднав у серію книг, що отримала назву Юрій Винничук презентує. До неї ввійшло вісім книг ${ }^{30}$. Оглядаючи список, можна стверджувати, що це нова серія українських видань елітарної та масової літератури. Зазначені видання не можна розглядати лише як комерційну діяльність письменника, ${ }^{31}$ адже під однією обкладинкою зібрані твори, об'єднані тематично, що значно полегшить роботу літературознавцеві.

Галицька кухня ${ }^{32}$ — це своєрідна енциклопедія кухні: готування, історії, ресторанного бізнесу та біографії найзнаковіших українців-сучасників. Це подарункове видання, ілюстроване фотографіями, що репрезентує культурологічний пласт, традиції та сімейні рецепти. Книга не лише розкриває таємниці галицької кухні, а й знайомить читачів зі смачними делікатесами Галичини, на сторінках видання можна знайти рецепти від Тараса Чубая, Кузьми Скрябіна, Тараса Прохаська, Віктора Морозова та інших відомих персоналій, розповіді про знакові постаті української культури, фестивалі, міста тощо. Особливість книги в тому, що кожну страву тут готує відомий галичанин за своїм сімейним рецептом.

На підставі проаналізованих антологій, укладених Ю. Винничуком, стверджуємо, що діяльність письменника - помітне явище в контексті сучасної української літератури. Антології привертають увагу широкого кола читачів до українськомовної книги, а ретельна робота письменника з архівними фондами бібліотек полегшує роботу літературознавцям, адже зібраний матеріал за однією тематикою вможливлює панорамне бачення матеріалу, а значить, конкретну проблематику.

${ }^{30}$ Серія Юрій Винничук презентує включає наступні твори: Ю. В инн и чук, Гопля і Піпля, Львів 2008; Ю. Винничук, Легенди Львова. Книга периа, Львів 2010; Ю. Винничук, Легенди Львова. Книга друга, Львів 2009; Ярина Джурик, Смерть виповзає з підвалів, Львів 2003, Іван Керницький, Герой передмістя, Львів 2003; Мечи слав Опалек, На щербатім львівськім бруиі, Львів 2002; Юрій В инничук, Сороміцькі оповідки, Львів 2008, Кримінальні загадки: Клуб комісара Бониа, Львів 2002.

${ }^{31}$ Г. Тар а сюк, Юрій Винничук: ,, Література - ие спосіб мого життя”, [в:] „Літературна Україна" 2005, 26 трав, с. 1-6.

${ }^{32}$ Ю. В инничук, Галицька кухня, Львів 2014, с. 496. 